\title{
Pengaruh Lingkungan Kerja, Budaya Organisasi dan Kepemimpinan Terhadap Kinerja Pegawai Kantor Kecamatan Sanga Desa Kabupaten Musi Banyuasin
}

\author{
Musyodik $^{1}$, Omar Hendro $^{2} \&$ Trisniarty Adjeng Moelyati ${ }^{3}$ \\ ${ }^{1}$ Sekdes Macang Sakti Kecamatan Sanga Desa MUBA \\ ${ }^{2,3}$ Universitas Muhammadiyah Palembang \\ Email: musyodikj@gmail.com
}

\begin{abstract}
The formulation of the problem in this study is how the influence of the work environment on employee performance, organizational culture on employee performance, leadership on employee performance and work environment, organizational culture and leadership on employee performance at the Sanga Desa District office. This research method uses descriptive and inferential statistical analysis, with multiple linear regression models. Statistical calculations, resulting in a regression equation $\mathrm{Y}=0.275+0.141 \mathrm{X} 1$ $+0.239 \mathrm{X} 2+0.311 \mathrm{X} 3$. The results of the study answered the problem formulation which is also the purpose of this study. First, the work environment, organizational culture and leadership together have a positive and significant effect on the performance of the employees of the Sanga Desa, Musi Banyuasin District office. Second, the work environment has a positive and significant effect on the performance of the employees of the Sanga Village office, Musi Banyuasin Regency. Third, organizational culture has a positive and significant effect on the performance of the employees of the Sanga Village office, Musi Banyuasin Regency. Fourth, leadership has a positive and significant effect on the performance of the office employees of Sanga Village, Musi Banyuasin District. Through regression analysis, it is concluded that culture and leadership are more dominant in performance than the work environment of employees. However, leadership is more dominant than the variables of work environment and organizational culture on employee performance. Good leadership, management will be effective in its implementation so that it has an impact on the performance of the employees of the Sanga Village office, Musi Banyuasin District. Researchers provide recommendations, first, employees must provide good service to the community. Second, employees must be able to work together to achieve job goals. Third, leadership. running good work standards and there must be training for employees. Fourth, means to improve the internet / intranet network signal used for recording e-KTP and online village entry and reporting. Fifth, competence to maintain open deliberations. Emphasized to employees in completing tasks and responsibilities must be in accordance with existing work procedures

Keywords: work environment, organizational culture, leadership and performance.
\end{abstract}

\section{Pendahuluan}

Lingkungan Kerja adalah segala sesuatu yang ada di sekitar para pekerja dan dapat mempengaruhi dirinya dalam melaksanakan tugas-tugas yang diembannya, misal kebersihan, hubungan antara karyawan dan pimpinan, tingkat kebisingan dan sebagainya.Lingkungan kerja mempunyai peranan besar terutama di dalam membentuk sikap kerja. Lingkungan kerja yang nyaman memacu pegawai untuk mengutarakan kepentingan dan ketidakpuasan tanpa adanya rasa takut akan tindakan balasan dan perhatian. Budaya organisasi merupakan suatu pola dasar dari pembagian asumsiasumsi, nilai-nilai, dan keyakinan-keyakinan yang dipertimbangkan menjadi cara yang sesuai dalam cara berpikir dan bertindak tentang sesuatu, memecahkan masalah dan 
kemungkinan-kemungkinan yang dihadapi organisasi. Menurut Cushway dan Lodge (2000) budaya organisasi merupakan sistem nilai organisasi dan akan mempengaruhi cara pekerjaan dilakukan dan cara para karyawan berperilaku. Disimpulkan bahwa yang dimaksud dengan budaya organisasi dalam penelitian ini adalah sistem nilai organisasi yang dianut oleh anggota organisasi, yang kemudian mempengaruhi cara bekerja dan berperilaku dari para anggota organisasi.Nilai-nilai organisasi akan menciptakan budaya organisasi yang kuat.Apabila budaya organisasi telah dipahami dan dipatuhi oleh segenap pegawai diharapkan pegawai dapat bekerja dengan lebih baik dan memiliki kinerja yang tinggi sehingga dapat melakukan pekerjaan secara optimal. Kepemimpinan yaitu orang yang berfungsi memimpin atau yang membimbing atau menuntun. Apabila seseorang sudah mulai berkeinginan mempengaruhi orang lain, maka disini kegiatan kepemimpinan mulai terlihat pengaruh dan kekuasaan mewarnai kegiatan kelompok tersebut. Menurut Syaiful (2018) Kepemimpinan (leadership) adalah serangkaian kemampuan dan sifat-sifat kepribadian dalam diri pemimpin itu sendiri seperti kewibawaan, keterampilan, pengetahuan dan kompetensi untuk dijadikan sebagai sarana meyakinkan orang-orang yang dipimpinnya agar mau dan dapat melaksanakan tugastugas yang dibebankan kepadanya dengan rela, penuh semangat, ada kegembiraan batin, serta merasa tidak terpaksa. Kepemimpinan merupakan kekuatan dinamis organisasi dalam rangka mencapai tujuan organisasi secara efektif. Kepemimpinan juga adalah proses seseorang untuk mempengaruhi sekelompok orang untuk mencapai tujuan.Fungsi kepemimpinan adalah menciptakan visi, mengembangkan budaya organisasi, menciptakan sinergi, memberdayakan pengikut menciptakan perubahan, memotivasi pengikut mewakili sistem sosialnya dan membelajarkan organisasi. Kinerja dari para pegawai membutuhkan lingkungan kerja yang medukung dalam membantu pemerintah melayani masyarakat yang tidak hanya sekedar mengandalkan kemampuannya saja, karena kemampuan tanpa didukung lingkungan kerja yang baik, tidak akan menghasilkan kinerja yang baik.Kemauan pegawai untuk berpartisipasi dalam organisasi dapat memberikan kontribusi yang positif terhadap kinerja pegawai. Melalui budaya kinerja yang ada dan kepemimpinan yang profesional.

Berdasarkan pengamatan awal, terhadap lingkungan kerja pegawai, budaya organisasi dan kepemimpinan pada kantor Kecamatan Sanga Desa, kinerja pegawai masih rendah. Fenomena kinerja pegawai tampaknya kinerja pegawai kelurahan belum maksimal. Hal ini dapat dilihat, dalam hubungannya dengan tujuan tampak sebagian pegawai belum memberikan pelayanan kepada masyarakat dengan baik. Masih ada pegawai yang belum mampu bekerja sama untuk mencapai tujuan pekerjaan. Dalam hubugannya dengan standar setiap pegawai masih ada yang belum memiliki penilaian kinerja yang baik. Masih ada pegawai yang bekerja belum tidak sesuai standar kerja. Selanjutnya alat dan prasarana kantor kelurahan secara umum sering hilangnya sinyal jaringan internet/intranet yang digunakan untuk perekaman KTP-el dan pengentrian dan pelaporan Desa secara online. Adapun kompetensi pegawai kelurahan secara umum setiap pegawai menerima jika terjadi perbedaan pendapat baik dalam menyelesaikan pekerjaan maupun pendapat walaupun sebagian masih ada yang tidak sependapat. Masih ada pegawai yang bekerja tidak sesuai dengan tugas pokok dan fungsinya masing-masing. dan dalam hubungannya dengan motif masih banyak pegawai jika ingin keluar kantor tidak izin kepada atasan terlebih dahulu. Sering dalam penyelesaian tugas dan tanggung jawab tidak sesuai dengan prosedur kerja yang ada. 
Fenomena yang terjadi pada lingkungan kerja yang belum sepenuhnya mendukung. Hal ini tampak dari ketersediaan fasilitas yang mana sarana dan prasarana yang berada dikantor belum sesuai dengan prosedur yang ada. Masih sering dalam pembuatan administrasi kependudukan terhambat dikarenakan seringnya mati lampu dan hilangnya sinyal dan komputer yang ada dikantor belum sesuai dengan jumlah pegawai yang ada dikantor. Hubungannya antar pegawai tampak masih ada pegawai yang belum bisa bekerja sama sehingga setiap ada perintah pekerjaan selalu menolak dengan alasan tidak bisa, sehingga akan tampak rasa kecemburuan sosial sehingga pegawai menjadi malas untuk bekerja lebih giat. Adapun sirkulasi udara tampak belum baik, suhu ruangan yang ada belum sesuai dengan kebutuhan pegawai. Keamanan di tempat kerja juga bermasalah karena belum adanya penjagaan dikantor kepala Desa sehingga pegawai menjaga kantor dengan mengunci kantor pada makan siang bahkan sebagian file-file dan barang berharga kantor dibawa pulang kerumah dan dibawa kembali keesokan harinya.

Fenomena yang terjadi pada budaya organisasi hal ini tampak dari hubungannya dalam inovatif dalam memperhitungkan resiko karena kepala desa tidak terlalu teliti dan cermat terhadap pegawai dalam melaksanakan tugas. Pegawai Masih kurang memiliki inisiatif dalam menghadapi masalah dalam pekerjaannya. Dalam hubungannya dengan perhatian pada setiap masalah secara detail didalam melakukan pekerjaan tampak belum ada penghargaan atas hasil kerja yang sesuai / melebihi standar yang ditetapkan. Belum adanya perhatian terhadap detail pada pekerjaan yang dilakukan. Adapun orientasi pada hasil yang akan dicapai tampak kepala desa lebih mengutamakan pada hasil kerja/keluaran dibandingkan proses pekerjaan itu sendiri dan setiap keputusankeputusan yang diambil tidak konsisten terhadap peningkatan hasil kerja para pegawainya. Selanjutnya hubungan dengan Agresif dalam bekerja secara umum tampak belum konsisten mendorong pegawai untuk mengembangkan dirinya. Masih adanya sikap kompetitif dalam bekerja dan pegawai masih ada yang sering menunda-nunda (tidak agresif) atau bersantai-santai dalam menyelesaikan pekerjaannya.

Fenomena kepemimpinan juga belum menunjukkan profesionalisme. Hal ini tampak dari kemampuan dalam kedudukan sebagai pengawas (supervisor ability) yang mana pimpinan belum memberikan tauladan pada semua pegawai. Masih ada pegawai yang belum menerima kompensasi sesuai dengan masa kerjanya. Adapun kebutuhan akan prestasi dalam bekerja masih belum tampak dalam mendelegasikan wewenang untuk menciptakan hubungan kerja yang menyenangkan. Masih ada pegawai yang tidak mau menerima saran dalam menyelesaikan tugas. Belum adanya pemberian bonus mendasar pada prestasi kerja bawahannya. Dalam hubungannya dengan ketegasan (decisiveness) tamapak pimpinan belum memberikan ketegasan bagi pegawai yang melakukan pelanggaran. Pimpinan dalam memberikan instruksi kerja masih belum terlalu jelas kepada pegawainya. Penelitian ini bertujuan menganalisis Pengaruh Lingkungan Kerja, Budaya Organisasi dan Kepemimpinan terhadap kinerja pegawai kantor Kecamatan Sanga Desa Kabupaten Musi Banyuasin.

\section{Tinjauan Literatur}

\subsection{Kinerja Pegawai}

Armstrong dikutip dalam Sopiah dan Sangadji (2018) Performance means behaviorurs and results, behaviours emanate from the performer and transform performance from 
the abstraction to action. Not just the instruments for results behaviours are also outcames in ther own right - the product of mental and physical effort applied to tasks and can be judged apart from results. (kinerja berarti perilaku dan hasil. Perilaku berasal dari pekerja dan mengubah kinerja dari abstrak menjadi tindakan. Bukan hanya instrumen untuk hasil, perilaku juga merupakan hasil dalam hak mereka sendiri, merupakan produk usaha mental dan fisik yang diterapkan pada tugas dan dapat dinilai terpisah dari hasil). Menurut, Wilson Bangun (2012) Kinerja (performance adalah hasil pekerjaan yang dicapai seseorang berdasarkan persyaratan-persyaratan pekerjaan (job reqirement).Fattah Husein dikutip dalam Ainsworth, Smith dan Millership (2017) Kinerja adalah titik ahir orang, sumber daya dan lingkungan tertentu yang dikumpulkan bersama-sama dengan maksud untuk menghasilkan hal-hal tertentu, apakah produk yang kasatmata atau jasa yang kurang terlihat langsung.

Menurut McClelland (2015), kinerja merupakan suatu fungsi dari motivasi dan kemampuan. Untuk menyelesaikan tugas atau pekerjaan, seseorang harus memiliki derajat kesediaan dan tingkat kemampuan tertentu. Kesediaan dan keterampilan seseorang tidaklah cukup efektif untuk mengerjakan sesuatu tanpa pemahaman yang jelas tentang apa yang akan dikerjakan dan bagaimana mengerjakannya.Menurut Siagian (2004). Kinerja merupakan perilaku nyata yang ditampilkan setiap orang sebagai prestasi kerja yang dihasilkan oleh pegawai sesuai dengan perannya dalam lembaga. Menurut Robbins (2002), Kinerja merupakan suatu fungsi dari motivasi dan kemampuan. untuk menyelesaikan suatu tugas atau pekerjaan, seseorang sepatutnya memiliki derajat kesediaan dan tingkat kemampuan tertentu. Berdasarkan pengertian menurut beberapa ahli diatas dapat ditarik kesimpulan bahwa kinerja adalah hasil kerja yang dicapai oleh seseorang atau sekelompok orang dalam melaksanakan tugasnya sesuai dengan wewenang, tanggung jawab dan beban kerja dalam rangka mencapai tujuan suatu organisasi.

\subsubsection{Faktor yang Mempengaruhi Kinerja}

Faktor-faktor yang mempengaruhi kinerja karyawan baik hasil maupun perilaku kerja menurut Kasmir di kutip dalam Rhisda Pangesti (2016) yaitu : 1).Kemampuan dan keahlian. 2). Pengetahuan, 3). Rancangan kerja, 4). Kepribadian, 5). Motivasi kerja, 6). Kepemimpinan, 7). Gaya kepemimpinan, 8). Budaya organisasi, 9). Kepuasan kerja, 10). Lingkungan kerja, 11). Loyalitas, 12).Komitmen, 13). Disiplin kerja

Dari beberapa faktor yang mempengaruhi kinerja karyawan diatas peneliti hanya mengangkat tiga faktor yang telah disesuaikan dengan keadaan obyek penelitain, yaitu faktor lingkungan kerja, Budaya organisasi dan kepemimpinan.

\subsubsection{Indikator Kinerja}

Menurut Wibowo (2017), terdapat tujuh indikator kinerja yaitu, 1). Tujuan (Goal), 2). Standar (Standart), 3). Umpan balik (Feedback), 4). Alat atau sarana (Mean), 5). Kompetensi (Competence), 6). Motif (Motive), 7). Peluang (Opportunity). Dari indikator kinerja pegawai di atas peneliti hanya mengambil 5 indikator yaitu : tujuan, standar, alat atau sarana Kompetensi dan Motif. 


\subsection{Lingkungan Kerja}

Sedarmayati dikutip dalam Sudario, Ariwibowo dan Sofiati (2018), lingkungan kerja adalah keseluruhan alat perkakas dan bahan yang dihadapi, lingkungan sekitar dimana seseorang bekerja, metode kerja, serta pengaturan kerja (baik sebagai perseorangan maupun sebagai kelompok). Gouzali Saydam dikutip dalam Mariati Rahman (2017), lingkungan kerja merupakan keseluruhan sarana dan prasarana kerja yang ada di sekitar karyawan yang sedang melakukan pekerjaan yang dapat mempengaruhi pelaksanaan pekerjaan itu sendiri. Lingkungan kerja adalah tempat di mana karyawan melakukan aktivitas setiap harinya. Lingkungan kerja dikatakan baik atau sesuai apabila karyawan dapat melaksanakan kegiatan secara optimal, sehat, aman dan nyaman. Berdasarkan beberapa pendapat para ahli diatas, dapat dikatakan bahwa lingkungan kerja merupakan segala sesuatu yang ada disekitar pegawai yang dapat mempengaruhi diri pegawai dalam menjalankan tugas yang dibebankan oleh suatu organisasi.Namun secara umum pengertian lingkungan kerja merupakan kondisi dan suasana dimana para pegawai tersebut melaksanakan tugas dan pekerjaannya dengan maksimal.

\subsubsection{Jenis Lingkungan Kerja}

Sedarmayanti (2011) menyatakan bahwa secara garis besar, jenis lingkungan kerja terbagi menjadi 2 yaitu, 1). Lingkungan Kerja Fisik, terdiri dari Lingkungan yang langsung berhubungan dengan karyawan (Seperti: pusat kerja, kursi, meja dan sebagainya), dan Lingkungan perantara atau lingkungan umum dapat juga disebut lingkungan kerja yang mempengaruhi kondisi manusia, misalnya: temperatur, kelembaban, sirkulasi udara, pencahayaan, kebisingan, getaran mekanis, bau tidak sedap, warna, dan lain-lain. 2). Lingkungan Kerja Non Fisik, yaitu semua keadaan yang terjadi yang berkaitan dengan hubungan kerja, baik hubungan dengan atasan maupun hubungan sesama rekan kerja, ataupun hubungan dengan bawahan.

\subsubsection{Indikator Lingkungan Kerja}

Indikator lingkungan kerja menurut Sedarmayati (2011), 1). Tersedianya Fasilitas, 2). Hubungan dengan Rekan Kerja, 3). Penerangan atau cahaya di tempat kerja. 4). Sirkulasi udara di tempat kerja, 5). Kebisingan di tempat kerja, 6). Polusi, 7). Bau tidak sedap di tempat kerja, 8). Keamanan di tempat kerja. Dari indikator Lingkungan Kerja di atas peneliti hanya mengambil 4 indikator yaitu : Tersedianya Fasilitas, Hubungan dengan rekan kerja, sirkulasi udara ditempat kerja dan keamanan ditempat kerja.

\subsection{Budaya Organisasi}

Menurut Edy Sutrisno (2018) budaya organisasi didefinisikan sebagai perangkat sistem nilai-nilai (values), keyakinan-keyakinan (beliefs), asumsi-asumsi (assumptions), atau norma-norma yang telah lama berlaku, disepakati dan diikuti oleh para anggota suatu organisasi sebagai pedoman berprilaku dan pemecahan masalah-masalah organisasinya.Edgar Schein (dikutip dalam Jhon, Robert dan Micael, 2006) mendefinisikan budaya organisasi sebagai suatu pola dari asumsi dasar yang diciptakan, ditemukan, atau dikembangkan oleh kelompok tertentu saat belajar menghadapi masalah adaptasi eksternal dan integrasi internal yang telah berjalan cukup baik untuk dianggap valid dan oleh karena itu, untuk diajarkan kepada anggota baru sebagai cara yang benar untuk berpersepsi, berfikir, dan berperasaan sehubungan dengan masalah yang dihadapinya.Dari definisi diatas dapat disimpulkan bahwa budaya organisasi adalah nilai-nilai atau norma-norma yang harus dipatuhi oleh anggota organisasi, baik 
secara sadar maupun tidak sadar, guna mencapai tujuan organisasi.

\subsubsection{Indikator Budaya Organisasi}

Untuk membentuk budaya organisasi yang baik, ada beberapa indikator budaya organisasi yang di kemukakan Hari Sulaksono (2019) yaitu, 1). Inovatif memperhitungkan Resiko, 2). Memberikan perhatian pada setiap masalah secara detail didalam melakukan pekerjaan, 3). Berorientasi pada hasil yang akan dicapai, 4). Berorientasi kepada semua kepentingan karyawan, 5). Agresif dalam bekerja, 6). Mempertahankan dan menjaga stabilitas kerja

\subsection{Kepemimpinan}

Menurut Koontz, et. al. dikutip dalam Bangun, Wilson (2012) kepemimpinan sebagai pengaruh, seni, atau proses memengaruhi orang-orang sehingga mereka akan berusaha dalam mencapai tujuan kelompok dengan kemauan dan antusias. Robbins di kutip dalam Kukuh Lukiyanto (2016) kepemimpinan adalah kemampuan untuk memengaruhi suatu kelompok guna mencapai serangkaian tujuan. Indra Prawira (2020) kepemimpian merupakan kemampuan individu dengan menggunakan kekuasaannya melakukan proses mempengaruhi, memotivasi, dan mendukung usaha yang memungkinkan orang lain memberikan kontribusi pada pencapaian tujuan organisasi. Sutarto Wijono (2018) Kepemimpinan (leadership) adalah proses memotivasi orang lain untuk mau bekerja dalam rangka mencapai tujuan yang telah ditetapkan. Sedangkan menurut Atika Syam (2016) kepemimpinan adalah mempengaruhi orang lain atau bawahan, tanpa bawahan pemimpin tidak akan ada. Tetapi proses pengaruh antara pimpinan dan bawahan tidak se arah. Pemimpin mempengaruhi bawahan, tetapi bawahan juga mempunyai beberapa pengaruh terhadap pemimpin.

\subsubsection{Gaya-gaya Kepemimpinan}

Menurut Malayu (2018) ada 4 gaya kepemimpinan yaitu, 1). Kepemimpinan otoriter. Kepemimpinan otoriter adalah jika kekuasaan atau wewenang sebagian besar mutlak tetap berada pada pimpinan atau pemimpin itu menganut sistem sentralisasi wewenang. Pengambilan keputusan dan kebijaksanaan hanya ditetapkan sendiri oleh pemimpin, bawahan tidak diikutsertakan untuk memberikan saran, ide, dan pertimbangan dalam proses pengambilan keputusan. 2) Kepemimpinan partisipatif, Kepemimpinan partisipatif adalah apabila dalam kepemimpinannya dilakukan dengan carapersuasive, menciptakan kerjasama yang serasi, menumbuhkan loyalitas, dan partisipasi para bawahan. Pemimpin memotivasi bawahan agar merasa ikut memiliki perusahaan. 3) Kepemimpinan delegatif, Kepemimpinan delegatif apabila seorang pemimpin mendelegasikan wewenang kepada bawahan dengan agak lengkap.Dengan demikian, bawahan dapat mengambil keputusan dan kebijaksanaan dengan bebas atau leluasa dalam melaksanakan pekerjaannya. 4) Kepemimpinan situasional, Kepemimpinan situasional adalah kepemimpinan yang berfokus pada pendekatan situasi yaitu situasi prilaku pemimpin dan bawahan yang sifatnya pariatif, jadi gaya kepemimpinan mana yang harus digunakan terhadap bawahan tergantung pada tingkat kesiapan orang yang akan dipengaruhi.

\subsubsection{Indikator Kepemimpinan}

Menurut Handoko (2009), ciri utama yang penting untuk kepemimpinan efektif antara lain: 1) Kemampuan dalam kedudukannya sebagai pengawas, (Supervisor ability)atau pelaksanaan fungsi-fungsi dasar manajemen terutama pengarahan dan pengawasan 
pekerjaan orang lain.2) Kebutuhan akan prestasi dalam bekerja, mencakup pencarian tanggung jawab dan keinginan sukses 3) Kecerdasan, mencakup kebijakan, pemikiran yang kreatif dan daya pikir.4) Ketegasan (decisiveness), atau kemampuan untuk membuat keputusan-keputusan dan memecahkan masalah-masalah dengan cakap dan tepat.5) Kepercayaan diri, atau pandangan terhadap dirinya sebagai kemampuan untuk menghadapi masalah.6) Inisiatif, atau kemampuan untuk bertindak tidak tergantung mengembangkan serangkaian kegiatan dan menemukan cara-cara baru atau inovasi.

\subsection{Kerangka Pemikiran}

Asumsi antara variabel lingkungan kerja, budaya organisasi dan kepemimpinan terhadap kinerja pegawai pada kantor Kecamatan Sanga Desa, bentuk pengaruh masingmasing variabel baik secara bersama-sama dapat dilihat dalam gambar kerangka pemikiran berikut ini :

Gambar .1.Kerangka Pemikiran

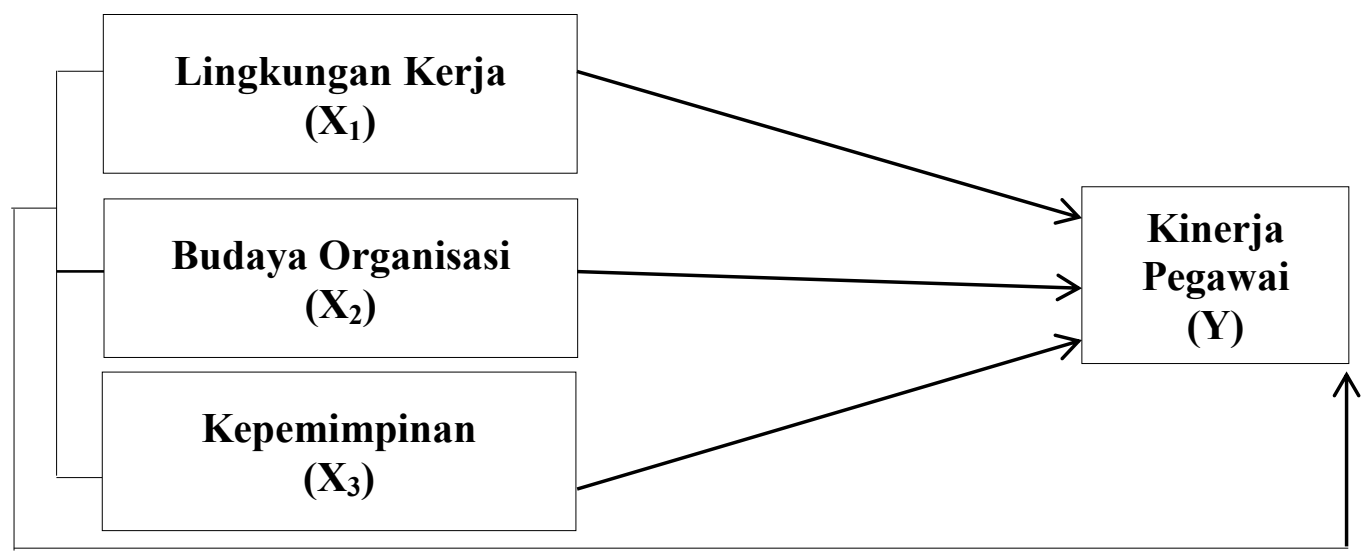

Sumber: Pemikiran Peneliti berdasar Teori, 2020

\section{Research Method}

Metode penelitian yang digunakan dalam penelitian ini adalah penelitian asosiatif. Menurut Sugiyono (2009) penelitian asosiatif adalah peneltian yang bertujuan untuk mengetahui hubungan antara dua variabel atau lebih. Dalam penelitian ini hubungan yang digunakan adalah hubungan yang kasual ini adalah hubungan yang bersifat sebab akibat.

Tabel 1. Operasionalisasi Variabel

\begin{tabular}{|c|c|c|c|c|}
\hline Variabel & $\begin{array}{c}\text { Definisi } \\
\text { Operasional }\end{array}$ & Indikator & Skala & $\begin{array}{c}\text { Item } \\
\text { Pertanyaan }\end{array}$ \\
\hline \multirow[t]{3}{*}{$\begin{array}{c}\text { Kinerja } \\
\text { Pegawai (Y) }\end{array}$} & \multirow{3}{*}{$\begin{array}{l}\text { hasil kerja yang } \\
\text { dicapai } \\
\text { pegawai dalam } \\
\text { melaksanakan } \\
\text { tugasnya sesuai } \\
\text { dengan }\end{array}$} & 1. Tujuan & Ordinal & 1,2 \\
\hline & & 2.Standar & Ordinal & 3,4 \\
\hline & & 3. Alat atau sarana & Ordinal & 5,6 \\
\hline
\end{tabular}




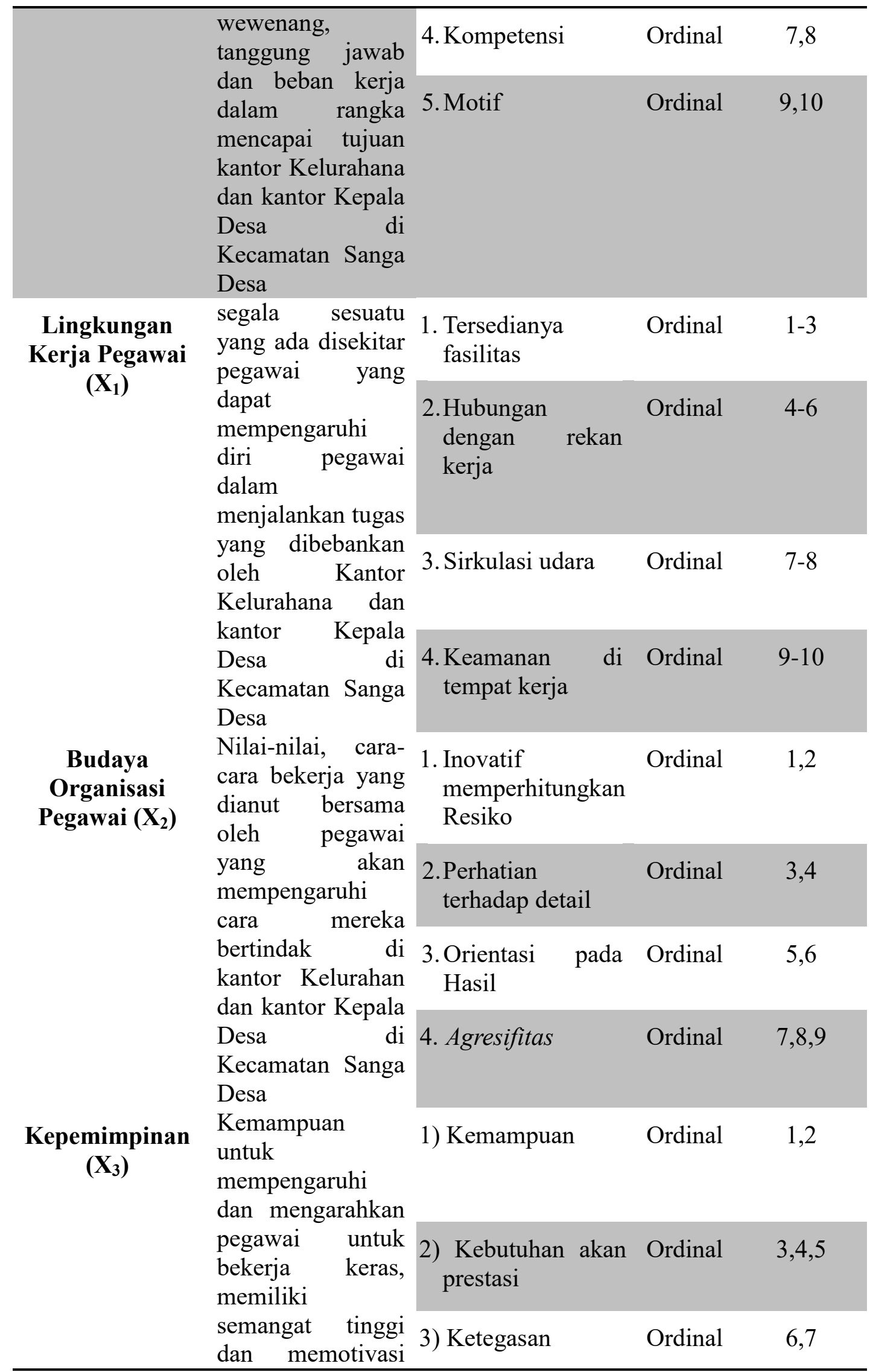




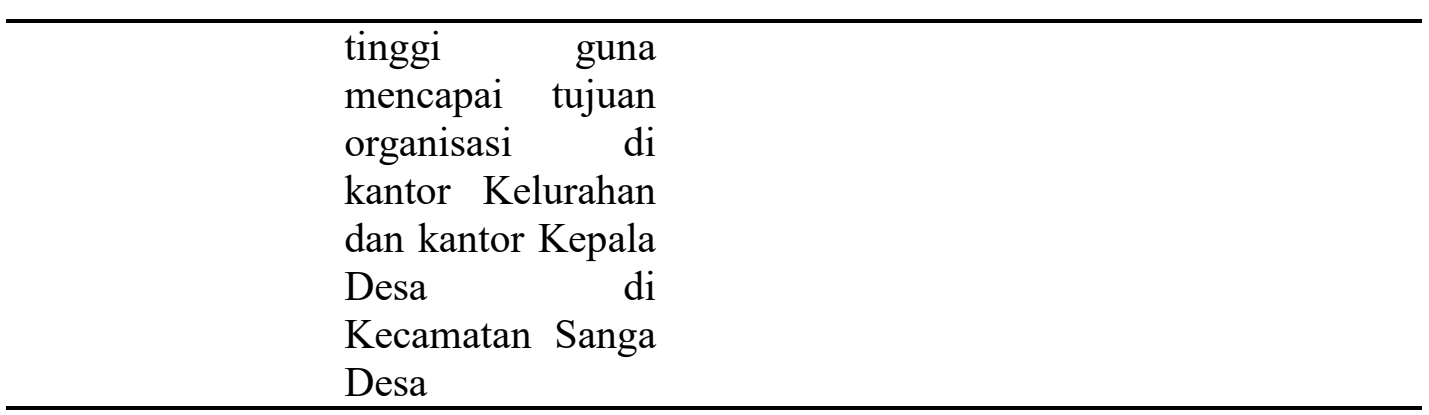

Sumber: Pemikiran Peneliti, berdasarkan Teori, 2020

Populasi dalam penelitian ini adalah pegawai seluruh kantor Kelurahan dan kantor Kepala Desa yang ada di Kecamatan Sanga Desa yang berjumlah 240 pegawai. Untuk memperoleh data yang dapat mewakili kantor Kelurahan dan kantor Desa dan pegawai dilakukan penarikan sampel secara Cluster Sampling (Area Sampling) menentukan sampel pegawai dari instansi yang terpilih dengan taraf kesalahan 5\% yaitu sebanyak 17 desa dan 2 kelurahan di Kecamatan Sanga Desa berjumlah 71 pegawai.Jumlah sampel 71 respoden, ini di karenakan pembulatan dalam tabel penentuan sampel berdasarkan jumlah keseluruhan pegawai kantor kelurahan atau desa di Kecamatan Sanga Desa Kabupaten Musi Banyuasin. Teknik pengambilan sampel, menggunakan Area sampling, yaitu pengambilan sampel secara sengaja atau sudah ditentukan (Fauzi, Dencik, Asiati., 2019)

\subsection{Uji Instrumen}

Untuk dapat memastikan bahwa ukuran yang dibuat adalah logis, hal yang harus dilakukan adalah menganalisis item terhadap respon atas pertanyaan yang mengungkap variabel, kemudian keandalan (reliable) dan keabsahan (validitas). menurut Sugiono (2009).

\subsection{Rancangan Analisis Data}

Rancangan analisis data yaitu 1). Uji Data, melalui Uji Normalitas, dan Uji Linearitas Data. 2). Uji Model, yaitu melakukan uji Multikolinearitas, dan Uji Heteroskedastisitas.3). Model Analisis, menggunakan analisis regresi linier berganda. Menurut Sanusi (2011), regresi linear berganda dapat diketahui melalui persamaan perhitungan sebagai berikut:

$$
\mathrm{Y}=\mathrm{a}+\mathrm{b}_{1} \mathrm{X}_{1}+\mathrm{b}_{2} \mathrm{X}_{2}+\mathrm{b}_{3} \mathrm{X}_{3}+\mathrm{e}
$$

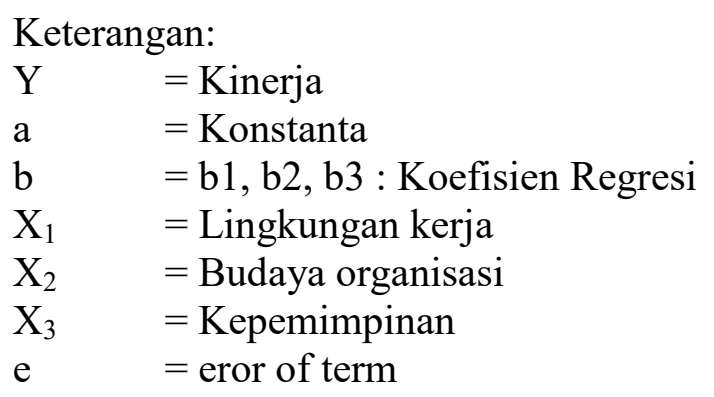


Uji Koefisien, yaitu 1). Uji secara bersama-sama (Uji F), untuk melihat pengaruh lingkungan kerja, budaya serta kepemimpinan secara bersama-sama terhadap kinerja pegawai Kantor Kecamatan Sanga DesaKabupaten Musi Banyuasin. 2). Uji secara parsial (Uji t), untuk melihat pengaruh lingkungan kerja, budaya organisasi dan kepemimpinan secara bersama-sama Terhadap kinerja pegawai Kantor Kecamatan Sanga Desa Kabupaten Musi Banyuasin

\section{Hasil dan Pembahasan}

\subsection{Hasil Penelitian}

\subsubsection{Hasil uji validitas}

1). Variabel Kinerja Pegawai (Y).

Dari tabel di atas didapat hasil uji validitas akan variabelVariabel Kinerja Pegawai(Y) dimana tidak terdapat item-item yang memiliki nilai corrected Item-Total Correlation $<0,3610$, sehingga semua item dalam variable Kinerja Pegawai(Y) ini dapat dipergunakan, sehingga pernyataan untuk variable Kinerja Pegawai(Y) terdiri dari 10 item, yang terdiri dari : $\mathrm{Y}_{1.1}, \mathrm{Y}_{1.2}, \mathrm{Y}_{1.3}, \mathrm{Y}_{1.4}, \mathrm{Y}_{1.5}, \mathrm{Y}_{1.6}, \mathrm{Y}_{1.7}, \mathrm{Y}_{1.8}, \mathrm{Y}_{1.9}, \mathrm{Y}_{1.10}$.

2). Variabel Lingkungan Kerja $\left(\mathrm{X}_{1}\right)$.

Dari hasil pengujian validitas terhadap item-item pada variable Lingkungan Kerja $\left(\mathrm{X}_{1}\right)$ seperti terlihat pada Tabel diatas, didapat hasil uji nilai hitung corrected Item-Total Correlation $>0,3610$ sehingga seluruh item dinyatakan valid, sehingga pernyataan untuk Variabel Lingkungan Kerja $\left(\mathrm{X}_{1}\right)$ terdiri dari 10 item, yaitu : $\mathrm{X}_{1.1}, \mathrm{X}_{1.2}, \mathrm{X}_{1.3}, \mathrm{X}_{1.4}, \mathrm{X}_{1.5}$, $\mathrm{X}_{1.6}, \mathrm{X}_{1.7}, \mathrm{X}_{1.8}, \mathrm{X}_{1.9}, \mathrm{X}_{1.10}$.

3). Variabel Budaya Organisasi $\left(X_{2}\right)$

Dari hasil pengujian validitas terhadap item-item pada Variable Budaya Organisasi $\left(\mathrm{X}_{2}\right)$ seperti terlihat pada Tabel diatas, didapat hasil uji nilai hitung corrected Item-Total Correlation $>0,3610$ sehingga seluruh item dinyatakan valid, sehingga pernyataan untuk Variabel Budaya Organisasi $\left(\mathrm{X}_{2}\right)$ terdiri dari 11 item, yaitu : $\mathrm{X}_{2.1}, \mathrm{X}_{2.2}, \mathrm{X}_{2.3}, \mathrm{X}_{2.4}, \mathrm{X}_{2.5}$, $\mathrm{X}_{2.6}, \mathrm{X}_{2.7}, \mathrm{X}_{2.8}, \mathrm{X}_{2.9}, \mathrm{X}_{2.10}, \mathrm{X}_{2.11}$.

4). Variabel Kepemimpinan $\left(X_{3}\right)$.

Dari hasil pengujian validitas terhadap item-item pada variable Kepemimpinan $\left(\mathrm{X}_{3}\right)$ seperti terlihat pada Tabel diatas, didapat hasil uji nilai hitung corrected Item-Total Correlation $>0,3610$ sehingga seluruh item dinyatakan valid, sehingga pernyataan untuk Variabel Kepemimpinan $\left(\mathrm{X}_{3}\right)$ terdiri dari 7 item, yaitu : $\mathrm{X}_{3.1}, \mathrm{X}_{3.2}, \mathrm{X}_{3.3}, \mathrm{X}_{3.4}, \mathrm{X}_{3.5}, \mathrm{X}_{3.6}$, $\mathrm{X}_{3.7}$.

\subsubsection{Uji Reliabilitas}

Uji reliabilitas digunakan untuk mengukur konsistensi konstruk atau variabel penelitian.Mengukur uji reliabilitas dilakukan dengan menggunakan uji statistik Cronbach Alpha. Suatu konstruk atau variabel dikatakan reliabel sedang jika memberikan nilai koefisien Cronbach's Alpha lebih besar daripada 0,60.

Hasil uji reliabilitas dalam penelitian ini dapat dilihat sebagai berikut: 
Tabel 2.Uji Reliabilitas Variabel X dan Y

\begin{tabular}{lll}
\hline Variabel & $\begin{array}{l}\text { cronbach' } \\
\text { alpha }\end{array}$ & $\begin{array}{l}\text { N of } \\
\text { item }\end{array}$ \\
\hline Lingkungan Kerja $\left(\mathbf{X}_{\mathbf{1}}\right)$ & 0,988 & 11 \\
\hline Budaya Organisasi $\left(\mathbf{X}_{\mathbf{2}}\right)$ & 0,984 & 12 \\
\hline Kepemimpinan $\left(\mathbf{X}_{\mathbf{3}}\right)$ & 0,992 & 8 \\
\hline Kinerja Pegawai $(\mathbf{Y})$ & 0,974 & 11 \\
\hline
\end{tabular}

Sumber: olah data primer, 2020

Hasil dari Tabel 2 dapat disimpulkan bahwa alat ukur yang digunakan dalam penelitian ini adalah reliabel.

\subsubsection{Hasil Uji Regresi}

Analisis regresi linier berganda digunakan dalam penelitian ini dengan tujuan untuk membuktikan hipotesis mengenai pengaruh Variabel Lingkungan Kerja $\left(\mathrm{X}_{1}\right)$ dan Budaya Organisasi $\left(\mathrm{X}_{2}\right)$ serta Kepemimpinan $\left(\mathrm{X}_{3}\right)$ terhadap Kinerja Pegawai(Y). Perhitungan statistik dalam analisis regresi linier berganda yang digunakan dalam penelitian ini adalah dengan menggunakan bantuan program komputer SPSS For Windows Relase 15.00. Hasil pengolahan datanya:

\section{Tabel 3. Hasil Koefisien Regresi Berganda}

\begin{tabular}{|c|c|c|c|c|c|c|c|c|}
\hline \multicolumn{9}{|c|}{ Coefficients $^{\mathrm{a}}$} \\
\hline \multirow[b]{2}{*}{ Model } & & \multicolumn{2}{|c|}{$\begin{array}{c}\text { Unstandardiz ed } \\
\text { Coefficients }\end{array}$} & \multirow{2}{*}{$\begin{array}{c}\text { Standardized } \\
\text { Coefficients } \\
\text { Beta } \\
\end{array}$} & \multirow[b]{2}{*}{$t$} & \multirow[b]{2}{*}{ Sig. } & \multicolumn{2}{|c|}{ Collinearity Statistics } \\
\hline & & $\mathrm{B}$ & Std. Error & & & & Tolerance & $\mathrm{VIF}$ \\
\hline 1 & (Constant) & .275 & .579 & & .474 & .637 & & \\
\hline & Lingkungan Kerja & .414 & .092 & .446 & 4.511 & .000 & .958 & 1.044 \\
\hline & Budaya Organisasi & .239 & .094 & .250 & 2.552 & .013 & .974 & 1.027 \\
\hline & Kepemimpinan & .311 & .077 & .404 & 4.037 & .000 & .936 & 1.069 \\
\hline
\end{tabular}

a. Dependent Variable: Kinerja Pegawai

Sumber : Hasil olah data primer, 2020

Berdasarkan tabel di atas maka didapat persamaan regresi sederhana berikut ini:

$$
Y=0,275+0,141 X_{1}+0,239 X_{2}+0,311 X_{3}
$$

Intepretasi dari persamaan regresi berganda mengenai pengaruh Variabel Lingkungan Kerja $\left(\mathrm{X}_{1}\right)$ dan Budaya Organisasi $\left(\mathrm{X}_{2}\right)$ serta Kepemimpinan $\left(\mathrm{X}_{3}\right)$ terhadap Kinerja Pegawai(Y) dapat dijelaskan sebagai berikut:

- Nilai konstanta sebesar 0,275 menunjukkanbahwajikaVariabel Lingkungan Kerja $\left(\mathrm{X}_{1}\right)$ dan Budaya Organisasi $\left(\mathrm{X}_{2}\right)$ serta Kepemimpinan $\left(\mathrm{X}_{3}\right)$, terhadap Variabel Terikat yaitu Kinerja Pegawai $\left(\mathrm{Y}_{1}\right)$ sebesar $\mathbf{0 , 2 7 5 .}$ 
- Koefisien regresi Variabel Lingkungan Kerja $\left(X_{1}\right)$, sebesar $\mathbf{0 , 4 1 4}$ berslope positif, hal ini menyatakan bahwa jika Lingkungan Kerja $\left(\mathrm{X}_{1}\right)$, mengalami kenaikan sebesar 1 satuan, maka Kinerja Pegawai(Y) akan mengalami peningkatan sebesar 0,414 atau dapat juga dikatakan bahwa semakin tinggi Lingkungan Kerja $\left(\mathrm{X}_{1}\right)$,seorang pegawai maka akan mampu meningkatkan Kinerja Pegawai (Y).

- Koefisien regresi Variabel Budaya Organisasi $\left(\mathrm{X}_{2}\right)$ sebesar 0,239 berslope positif, hal ini menyatakan bahwa jika Budaya Organisasi $\left(\mathrm{X}_{2}\right)$ mengalami kenaikan sebesar 1 satuan, maka Kinerja Pegawai (Y) akan mengalami peningkatan sebesar 0,239 atau dapat juga dikatakan bahwa semakin baik Budaya Organisasi $\left(\mathrm{X}_{2}\right)$ maka akan mampu meningkatkan Kinerja Pegawai (Y).

- Koefisien regresi Variabel Kepemimpinan $\left(\mathrm{X}_{3}\right)$ sebesar 0,311 berslope positif, hal ini menyatakan bahwa jika Kepemimpinan $\left(\mathrm{X}_{3}\right)$ mengalami kenaikan sebesar 1 satuan, maka Kinerja Pegawai (Y) akan mengalami peningkatan sebesar 0,311 atau dapat juga dikatakan bahwa semakin baik Kepemimpinan $\left(\mathrm{X}_{3}\right)$ maka akan mampu meningkatkan Kinerja Pegawai (Y).

- Ketiga koefisien variabel bebas berslope positif, hal ini menunjukkan hubungan linier positif (searah) antara Variabel Lingkungan Kerja $\left(\mathrm{X}_{1}\right)$ dan Budaya Organisasi $\left(\mathrm{X}_{2}\right)$ serta Kepemimpinan $\left(\mathrm{X}_{3}\right)$, terhadap Variabel Terikat yaitu Kinerja Pegawai $\left(\mathrm{Y}_{1}\right)$ artinya Lingkungan Kerja $\left(\mathrm{X}_{1}\right)$ dan Budaya Organisasi $\left(\mathrm{X}_{2}\right)$ serta Kepemimpinan $\left(\mathrm{X}_{3}\right)$ yang semakin baik, maka semakin baik pula KinerjaPegawai(Y).

\subsubsection{Hasil Uji Korelasi dan Koefisien Determinasi.}

1) Uji Korelasi (R)

Analisis korelasi adalah salah satu teknik statistik yang digunakan untuk mencari hubungan antara dua variabel atau lebih yang sifatnya kuantitatif. Fungsi utama dari analisis korelasi adalah untuk menentukan seberapa erat hubungan antara satu variabel dengan variabel lainnya. Analisis Korelasi bertujuan untuk mengukur kekuatan hubungan antara dua variabel, analisis korelasi tidakmembedakan antara variabel dependen dengan independen.

Dari hasil estimasi data rekap jawaban responden, maka hasil koefisien korelasi dapat dijelaskan melalui tabel berikut ini :

Tabel 4. Hasil Uji Korelasi

\begin{tabular}{|c|c|c|c|c|c|}
\hline \multicolumn{6}{|c|}{ Model Summary } \\
\hline Model & $\mathrm{R}$ & R Square & $\begin{array}{l}\text { Adjusted } \\
\text { R Square }\end{array}$ & $\begin{array}{l}\text { Std. Error of } \\
\text { the Estimate }\end{array}$ & $\begin{array}{l}\text { Durbin- } \\
\text { Watson }\end{array}$ \\
\hline 1 & $.563^{a}$ & .317 & .289 & 1.032094 & 1.782 \\
\hline
\end{tabular}

Sumber : Hasil olah data primer, 2020

Berdasarkan hasil perhitungan, diperoleh nilai koefisien korelasi $(\mathrm{R})$ sebesar 0,869. Dari hasil yang didapat dengan mengkaitkan hasil koefisien korelasi dengan tingkat keeratan antara variabel sebesar 0,563 yang berada pada interpretasi nilai korelasi $(0,40-5,99)$ 
artinya bahwa hubungan kedua variabel signifikan dan tingkat keeratannya Sedang. Dimana data interprestasi kolerasinya sebagai berikut :

2) Uji Koefiien Korelasi $\left(R^{2}\right)$.

Koefisien Determinasi digunakan dalam kaitannya dengan penggunaan analisis kolerasi untuk melihat besar kecilnya besaran kontribusi atas variabel bebas menjelaskan variabel terikat.Koefisien determinasi disebut juga koefisien penentu, karena varian yang terjadi pada variabel dependen dapat dijelaskan melalui variabel independen.

Dari hasil estimasi data rekap jawaban responden, maka hasil Koefisien Determinasi dapat dijelaskan melalui tabel berikut ini :

Tabel 5. Hasil Uji Koefisien Determinasi

\section{Model Summary $\boldsymbol{y}^{\natural}$}

\begin{tabular}{|l|r|r|r|r|r|}
\hline Model & \multicolumn{1}{|c|}{$\mathrm{R}$} & R Square & $\begin{array}{c}\text { Adjusted } \\
\text { R Square }\end{array}$ & $\begin{array}{c}\text { Std. Error of } \\
\text { the Estimate }\end{array}$ & $\begin{array}{c}\text { Durbin- } \\
\text { Watson }\end{array}$ \\
\hline 1 & $.563^{\mathrm{a}}$ & .317 & .289 & 1.032094 & 1.782 \\
\hline
\end{tabular}

a. Predictors: (Constant), Kepemimpinan, Budaya Organisasi, Lingkungan Kerja

b. Dependent Variable: Kinerja Pegawai

Sumber : Hasil olah data primer, 2020

Hasil perhitungan dengan penggunaan program SPSS For Lingkungan Kerja $\left(\mathrm{X}_{1}\right)$ dan Budaya Organisasi $\left(\mathrm{X}_{2}\right)$ serta Kepemimpinan $\left(\mathrm{X}_{3}\right)$ mampu menjelaskan Variabel Kinerja Pegawai sebesar 0,317 atau $31,7 \%$, sedangkan sisanya sebesar $68,3 \%$ dijelaskan oleh faktor lain yang tidak diteliti. Dikarenakan berdasarkan tabel di atas, nilai koefisien determinasi yang dinilai tinggiyaitu sebesar 31,7\%, maka dalam hal ini peneliti memberikan rekomendasi kepada peneliti yang lain untuk dapat melakukan penelitian serupa guna menyempurnakan penelitian ini dengan variabel lainnya diluar variabel yang sedang peneliti gunakan saat ini.

\subsubsection{Uji Hipotesis}

1) Uji t (t-test).

Uji t digunakan untuk menguji apakah terdapat pengaruh signifikasn antara Variabel Lingkungan Kerja $\left(\mathrm{X}_{1}\right)$ dan Budaya Organisasi $\left(\mathrm{X}_{2}\right)$ serta Kepemimpinan $\left(\mathrm{X}_{3}\right)$, terhadap Variabel Terikat yaitu Kinerja Pegawai $\left(\mathrm{Y}_{1}\right)$. Untuk menentukan apakah hipotesis yang diajukan signifikan atau tidak, maka perlu dilihat dari estimasi t-hitung yang ditunjukan oleh tabel berikut ini : 
Tabel 6. Hasil Uji Hipotesis (Uji t)

\begin{tabular}{|c|c|c|c|c|c|c|c|c|}
\hline \multicolumn{9}{|c|}{ Coefficients ${ }^{\mathrm{a}}$} \\
\hline & & \multicolumn{2}{|c|}{$\begin{array}{l}\text { Unstandardized } \\
\text { Coefficients }\end{array}$} & \multirow{2}{*}{$\begin{array}{c}\text { Standardized } \\
\text { Coefficients } \\
\text { Beta }\end{array}$} & \multirow[b]{2}{*}{$t$} & \multirow[b]{2}{*}{ Sig. } & \multicolumn{2}{|c|}{ Collinearity Statistics } \\
\hline \multicolumn{2}{|c|}{ Model } & $B$ & Std. Error & & & & Tolerance & VIF \\
\hline \multirow[t]{4}{*}{1} & (Constant) & .275 & .579 & & .474 & .637 & & \\
\hline & Lingkungan Kerja & .414 & .092 & .446 & 4.511 & .000 & .958 & 1.044 \\
\hline & Budaya Organisasi & .239 & .094 & .250 & 2.552 & .013 & .974 & 1.027 \\
\hline & Kepemimpinan & .311 & .077 & .404 & 4.037 & .000 & .936 & 1.069 \\
\hline
\end{tabular}

a. Dependent Variable: Kinerja Pegawai

Sumber : Data (diolah) SPSS, 2020

Berdasarkan tabel di atas dapat diketahui bahwa nilai thitung untuk Variabel Lingkungan Kerja $\left(\mathrm{X}_{1}\right)$ adalah sebesar 4,511, Budaya Organisasi $\left(\mathrm{X}_{2}\right)$ adalah sebesar2,552danKepemimpinan $\left(\mathrm{X}_{3}\right)$ adalah sebesar 4,037, terhadap Variabel Terikat yaitu Kinerja Pegawai $\left(\mathrm{Y}_{1}\right)$ jika dibandingkan dengan $\mathrm{t}_{\text {tabel }}=1,99254$. Hasil estimasi tersebut menyatakan bahwa nilai $t_{\text {hitung }}$ ketiga variabel bebas atas variabel terikat lebih besar dari $t_{\text {tabel }}\left(t_{\text {hitung }}>t_{\text {tabel }}\right)$, maka kreteria Ha diterima dan Ho ditolak, hal ini berarti ketiga variabel bebas dapat dikatakan berpengaruh signifikan terhadap variabel terikat. Disisi lain, jika dibandingkan antara nilai koefisien Sig. dengan nilai P-value $(\alpha)$ sebesar 0,05, maka dapat diketahui bahwa koefisien Sig. variabel $X_{1}$ sebesar 0,000, koefisien Sig. variabel $\mathrm{X}_{2}$ sebesar 0,013, koefisien Sig. variabel $\mathrm{X}_{3}$ sebesar 0,000, ketiga variabel bebas tersebut memiliki nilai koefisien Sig. yang masih dibawah nilai P-value $(\alpha)$, hal ini berarti $\mathrm{H}_{\mathrm{a}}$ diterima dan $\mathrm{H}_{0}$ ditolak, artinya bahwa ada hubungan secara signifikan antara Variabel Lingkungan Kerja $\left(\mathrm{X}_{1}\right)$ dan Budaya Organisasi $\left(\mathrm{X}_{2}\right)$ serta Kepemimpinan $\left(\mathrm{X}_{3}\right)$, terhadap Variabel Terikat yaitu Kinerja Pegawai $\left(\mathrm{Y}_{1}\right)$.

Hipotesis satu, lingkungan kerja berpengaruh signifikan terhadap kinerja pegawai. Hasil perhitungan menghasilkan, Variabel Lingkungan Kerja $\left(\mathrm{X}_{1}\right)$ adalah sebesar 4,511, lebih besar terhadap Variabel Terikat yaitu Kinerja Pegawai $\left(\mathrm{Y}_{1}\right)$ jika dibandingkan dengan $\mathrm{t}_{\text {tabel }}=1,99254$.

Hipotesis dua, budaya organisasi berpengaruh signifikan terhadap kinerja pegawai. Hasil perhitungan menghasilkan, Budaya Organisasi $\left(\mathrm{X}_{2}\right)$ adalah sebesar2,552 lebih besar terhadap Variabel Terikat yaitu Kinerja Pegawai $\left(\mathrm{Y}_{1}\right)$ jika dibandingkan dengan $t_{\text {tabel }}=1,99254$.

Hipotesis ketiga, kepemimpinan berpengaruh signifikan terhadap kinerja. Hasil perhitungan menghasilkan, Variabel Kepemimpinan $\left(\mathrm{X}_{3}\right)$ adalah sebesar 4,037, lebih besar terhadap Variabel Terikat yaitu Kinerja Pegawai $\left(\mathrm{Y}_{1}\right)$ jika dibandingkan dengan $t_{\text {tabel }}=1,99254$.

2) Uji F (F-test)

Hasil analisis data dengan menggunakan program SPSS For Windows Relase 15.00 dapat disajikan dalam tabel berikut: 
Tabel 7. Hasil Uji F (F- test)

ANOVA

\begin{tabular}{|c|c|c|c|c|c|c|}
\hline Model & & $\begin{array}{c}\text { Sum of } \\
\text { Squares }\end{array}$ & $\mathrm{df}$ & Mean Square & $\mathrm{F}$ & Sig. \\
\hline \multirow[t]{3}{*}{1} & Regression & 36.111 & 3 & 12.037 & 11.300 & $.000^{\mathrm{a}}$ \\
\hline & Residual & 77.761 & 73 & 1.065 & & \\
\hline & Total & 113.872 & 76 & & & \\
\hline
\end{tabular}

a. Predictors: (Constant), Kepemimpinan, Budaya Organisasi, Lingkungan Kerja

b. Dependent Variable: Kinerja Pegawai

\section{Sumber : Hasil olah data primer, 2020}

Dari tabel di atas, diketahui nilai $\mathrm{F}_{\text {hitung }}$ sebesar 11,300> nilai $\mathrm{F}_{\text {tabel }}$ sebesar 2,73 dan dikuatkan dengan nilai koefisien sig. $F_{\text {hitung }}$ sebesar $0,000<$ P-value $(\alpha)$ sebesar 0,05.Berdasarkan kriteria pengujiannya adalah jika nilai koefisien sig. $\mathrm{F}<\mathrm{P}$-value $(\alpha)$ sebesar 0,05 berarti $\mathrm{H}_{\mathrm{a}}$ diterima dan $\mathrm{H}_{\mathrm{o}}$ ditolak.Maka dapat disimpulkan bahwa bahwa ada hubungan secara signifikan antara Variabel Lingkungan Kerja $\left(\mathrm{X}_{1}\right)$ dan Budaya Organisasi $\left(\mathrm{X}_{2}\right)$ serta Kepemimpinan $\left(\mathrm{X}_{3}\right)$, terhadap Variabel Terikat yaitu Kinerja Pegawai (Y).

Hipotesis empat, Lingkungan Kerja $\left(\mathrm{X}_{1}\right)$ dan Budaya Organisasi $\left(\mathrm{X}_{2}\right)$ serta Kepemimpinan $\left(\mathrm{X}_{3}\right)$, berpengaruh signifikan terhadap Variabel Terikat yaitu Kinerja Pegawai (Y)

\subsection{Pembahasan}

a. Pengaruh lingkungan kerja terhadap kinerja pegawai pada kantor Kecamatan Sanga Desa Kabupaten MUBA

Hipotesis satu, lingkungan kerja berpengaruh signifikan terhadap kinerja pegawai. Penelitian ini sesuai dengan teori Sedarmayati dikutip dalam Sudario, Ariwibowo dan Sofiati (2018) secara garis besar lingkungan kerja yang baik dan memenuhi syarat adalah lingkungan atau kondisi fisik tempat kerja yang dapat mempengaruhi atau meningkatkan efisiensi kerja. Penelitian ini mempunyai kesamaan dengan hasil penelitian Ana Sriekaningsih (2017) dan Tri Widodo (2010) penelitian mereka menyatakan terdapat pengaruh positif dan signifikan variabel lingkungan kerja kinerja pegawai.

b. Pengaruh budaya organisasi terhadap kinerja pegawai pada kantor Kecamatan Sanga Desa Kabupaten MUBA

Hipotesis dua, budaya organisasi berpengaruh signifikan terhadap kinerja pegawai. Hasil penelitian ini seperti teori yang di kemukakan oleh Busro (2018), Budaya Organisasi adalah persepsi bersama yang dianut oleh anggota organisasi sebagai suatu sistem organisasi yang dianut oleh anggota organisasi, yang kemudian memengaruhi cara bekerja berperilaku dari para anggota organisasi. Ini menyatakan bahwa budaya organisasi bepengaruh terhadap perilaku atau kinerja pegawai.

Penelitian ini mempunyai kesamaan dengan penelitian sebelumnya, yaitu Ana Sriekaningsih (2017), Tri Widodo (2010) dan Catur Windaryadi (2018), penelitian 
mereka menyimpulkan Budaya Organisasi berpengaruh signifikan terhadap Kinerja Pegawai.

c. Pengaruh Kepemimpinan terhadap kinerja pegawai pada kantor Kecamatan Sanga DesaKabupaten MUBA

Hipotesis ketiga, kepemimpinan berpengaruh signifikan terhadap kinerja. Hasil perhitungan menghasilkan, Variabel Kepemimpinan $\left(X_{3}\right)$ adalah sebesar 4,037, lebih besar terhadap Variabel Terikat yaitu Kinerja Pegawai $\left(\mathrm{Y}_{1}\right)$ jika dibandingkan dengan $t_{\text {tabel }}=1,99254$.

Hasil penelitian ini sesuai dengan teori yang di kemukakan Syaiful (2018), Kepemimpinan ( leadership )adalah serangkaian kemampuan dan sifat-sifat kepribadian dalam diri pemimpin itu sendiri seperti kewibawaan, keterampilan, pengetahuan dan kompetensi untuk dijadikan sebagai sarana meyakinkan orang-orang yang dipimpinnya agar mau dan dapat melaksanakan tugas-tugas yang dibebankan kepadanya dengan rela, penuh semangat, ada kegembiraan batin, serta merasa tidak terpaksa. Kepemimpinan merupakan kekuatan dinamis organisasi dalam rangka mencapai tujuan organisasi secara efektif.Kalimat di atas menyatakan bahwa kepemimpinan berpengaruh dengan kinerja bawahan yang dipimpin oleh seorang pemimpin.Penelitian ini juga sama hasilnya dengan penelitian Ana Sriekaningsih (2017), Tri Widodo (2010), dan Catur Windaryadi (2018), hasil penelitian para peneliti ini menyiimpulkan, ada pengaruh signifikan Kepemimpinan terhadap kinerja pegawai.

d. Pengaruh lingkungan kerja, budaya organisasi dan kepemimpinan terhadap kinerja pegawai pada kantor Kecamatan Sanga Desa Kabupaten MUBA.

Hipotesis empat, Lingkungan Kerja $\left(\mathrm{X}_{1}\right)$ dan Budaya Organisasi $\left(\mathrm{X}_{2}\right)$ serta Kepemimpinan $\left(\mathrm{X}_{3}\right)$, berpengaruh signifikan terhadap Variabel Terikat yaitu Kinerja Pegawai (Y).

Penelitian ini sesuai teori yang dikemukakan Kasmir di kutip dalam Rhisda Pangesti (2016), yaitu budaya organisasi, lingkungan dan kepemimpinan bagian dari faktorfaktor yang mempengaruhi kinerja pegawai.Kepemimpinan merupakan perilaku seseorang pemimpin dalam mengatur, mengelola dan memerintah bawahannya untuk mengerjakan suatu tugas dan tanggung jawab yang diberikannya.Budaya organisasi, merupakan kebiasaan-kebiasaan atau norma-norma yang berlaku dan dimilik suatu organisasi atau perusahaan. Kebiasaan-kebiasaan atau norma- norma ini mengatur halhal yang berlaku dan diterima secara umum serta harus dipatuhi oleh segenap anggota suatu perusahaan. Lingkungan kerja, merupakan suasana atau kondisi lokasi tempat bekerja.Lingkungan kerja dapat berupa ruangan, layout, sarana dan prasana, serta hubungan kerja dengan sesama rekan kerja. Jika lingkungan kerja dapat membuat suasana nyaman dan memberikan ketenangan maka akan membuat suasana kerja menjadi kondusif, sehingga dapat meningkatkan hasil kerja seseorang menjadi lebih baik, karena bekerja tanpa gangguan. Namun sebaliknya jika suasana atau kondisi lingkukngan kerja tidak memberikan kenyamanan atau ketenangan, maka akan berakibat suasana kerja menjadi terganggu yang pada akhirnya akan mempengaruhi dalam bekerja. Dengan demikian, dapat dikatakan bahwa lingkungan kerja memengaruhi kinerja seseorang/pegawai.

Penelitian ini mempunyai kesamaan dengan penelitian, Ana Sriekaningsih (2017), 
temuan penelitian menunjukkan bahwa kepemimpinan, budaya organisasi dan lingkungan kerja yang positif dan signifikan terhadap kinerja pegawai.Tri Widodo (2010), terdapat pengaruh positif dan signifikan secara simultan variabel lingkungan kerja, budaya organisasi dan kepemimpinan terhadap kinerja pegawai Kecamatan Sidorejo Kota Salatiga

\subsection{Implikasi Penelitian}

Peneliti mencoba memberikan rekomendasi dalam penelitian ini, yang juga merupakan implikasi penelitian. Rekomendasi ini peneliti uraikan berdasarkan masing-masing indikator dari variabel. Pertama, Kinerja Pegawai pada indikator tujuan pegawai harus memberikan pelayanan kepada masyarakat dengan baik. Pegawai harus mampu bekerja sama untuk mencapai tujuan pekerjaan. Indikator standar pegawai harus memiliki penilaian kinerja yang baik oleh Pimpinan. Untuk mendapatkan standar kerja yang baik harus adanya pelatihan-pelatihan terhadap pegawai. Indikator alat atau sarana untuk ditingkatkan sinyal jaringan internet/intranet yang digunakan untuk perekaman KTP-el dan pengentrian dan pelaporan Desa secara online. Indikator kompetensi untuk tetap dipertahankan musyawarah terbuka walaupun terjadi perbedaan pendapat baik dalam menyelesaikan pekerjaan maupun pendapat walaupun sebagian masih ada yang tidak sependapat. Adakan refresh jobdesk sehingga pegawai bekerja sesuai dengan tugas pokok dan fungsinya masing-masing. Indikator motif untuk

dilakukan absen pegawai sehingga jika ingin keluar kantor harus izin kepada atasan terlebih dahulu. Ditekankan kepada pegawai dalam penyelesaian tugas dan tanggung jawab harus sesuai dengan prosedur kerja yang ada.

Kedua, Lingkungan Kerja pada indikator tersedianya fasilitas, untuk ditingkatkan ketersediaan fasilitas sarana dan prasarana yang berada dikantor karena masih ada fasilitas belum sesuai dengan prosedur yang ada. Untuk ditingkatkan pelayanan pembuatan administrasi kependudukan karena sering terhambat dikarenakan seringnya mati lampu dan hilangnya sinyal. Kkomputer yang ada dikantor harus sesuai dengan jumlah pegawai yang ada dikantor. Indikator hubungan dengan rekan kerja, adakan secara periodik pelatihan pegawai kantor untuk meningkatkan kinerja pegawai, sehingga setiap ada perintah pekerjaan, pegawai bisa dan mampu menyelesaikannya dengan baik. Agar tidak ada kecemburuan sosial pegawai dalam bekerja. Indikator sirkulasi udara, perbaiki sirkulasi udara, suhu ruangan yang ada karena belum sesuai dengan kebutuhan pegawai. Indikator keamanan di tempat kerja, tingkatkan

keamanan di tempat kerja atau aktifkan hansip desa dikantor kepala Desa sehingga pegawai merasa aman di lingkungan kerjanya.

Ketiga, Budaya Organisasi pada indikator inovatif memperhitungkan resiko, hendaknya kepala desa teliti dan cermat terhadap pegawai dalam melaksanakan tugas. Berikan kebebasan pegawai berinisiatif dalam menghadapi masalah dalam pekerjaannya. Indikator perhatian terhadap detail, belum adanya penghargaan atas hasil kerja yang sesuai / melebihi standar yang ditetapkan. Hendaknya Kepala desa memberikan perhatian terhadap detail pada pekerjaan yang dilakukan. Indikator orientasi pada Hasil, kepala desa selain mengutamakan pada hasil kerja/keluaran harus mengawasi/memperhatikan proses pekerjaan itu sendiri. Hendaknya keputusankeputusan yang diambil konsisten terhadap peningkatan hasil kerja para pegawainya. Indikator agresifitas, perlunya konsisten pimpinan untuk mendorong pegawai 
mengembangkan dirinya. Perlunya penegasan kepada pegawai untuk tidak menundanunda (tidak agresif) atau bersantai-santai dalam menyelesaikan pekerjaannya.

Keempat, Kepemimpinan pada indikator kemampuan, kepala desa sebagai pengawas (supervisor ability) yang mana pimpinan harus memberikan tauladan pada semua pegawai. Hendaknya pegawai yang ada harus menerima kompensasi sesuai dengan masa kerjanya. Indikator kebutuhan akan prestasi, perlunya pendelegasian wewenang kepada pegawai untuk menciptakan hubungan kerja yang menyenangkan. Hendaknya pegawai mau menerima saran dalam menyelesaikan tugas. Harus ada pemberian bonus mendasar pada prestasi kerja bawahannya. Indikator ketegasan, perlunya ketegasan (decisiveness) pimpinan bagi pegawai yang melakukan pelanggaran. Pimpinan dalam memberikan instruksi kerja harus jelas kepada pegawainya.

\section{Kesimpulan}

Pertama, Lingkungan kerja, budaya organisasi serta kepemimpinan secara bersamasama berpengaruh positif dan signifikan terhadap kinerja pegawai kantor Kecamatan Sanga Desa Kabupaten Musi Banyuasin. Kedua, Lingkungan kerja berpengaruh positif dan signifikan terhadap kinerja pegawai kantor Kecamatan Sanga Desa Kabupaten Musi Banyuasin. Ketiga, Budaya organisasi berpengaruh positif dan signifikan terhadap kinerja pegawai kantor Kecamatan Sanga Desa Kabupaten Musi Banyuasin. Keempat, Kepemimpinan berpengaruh positif dan signifikan terhadap kinerja pegawai kantor Kecamatan Sanga Desa Kabupaten Musi Banyuasin.

Saran, peneliti memberikan saran pertama, Lurah dan Kepala Desa di kecamatan Sanga Desa perlu untuk meningkatkan komunikasi kepada pegawai secara langsung dan tatap muka, sehingga terjalin kerjasama yang optimal dalam pencapaian tujuan dari organisasi. Kedua, Lurah dan Kepala Desa di kecamatan Sanga Desa perlu meningkatkan kesadaran pegawai akan adanya tindakan korektif pada setiap mengalami kesalahan dalam melakukan pekerjaan dan meninggalkan budaya yang tidak baik serta bisa menerima dan melakukan budaya yang baik. Ketiga, Lurah dan Kepala Desa di kecamatan Sanga Desa hendaknya mengevaluasi kembali hasil kerja pegawai, sehingga dapat menimbulkan perilaku yang positif sesuai dengan etos kerja yang diharapkan. Untuk itu, perlu diperhatikan faktor-faktor internal dan eksternal yang menunjang sarana dan prasarana kerja termasuk keteladanan dan manajerial. Hal yang tidak kalah pentingnya adalah memberikan Reward dan panishment bagi pegawai secara terukur dan adil. Keempat, peneliti yang akan datang hendaknya menambah variabel yang lain untuk melengkapi penelitian yang telah dilakukan.

\section{Referensi}

Bangun, W. (2012). Manajemen Sumber Daya Manusia. Jakarta : Erlangga

Fauzi, F., Dencik, A. B., \& Asiati, D. I. (2019). Metodologi Penelitian untuk manajemen dan akuntansi. Jakarta: Salemba Empat.

Kasmir. (2018). Cetakan Ke Lima. Manajemen Sumber Daya Manusia. Depok : Rajawali

Sanusi, A. (2011). Metodologi Penelitian Bisnis. Jakarta Selatan: Penerbit Salemba

Sedarmayanti. (2011). Sumber Daya Manusia dan Produktivitas Kerja. Bandung: Mandar Maju 
Siagian, P.S. (2018). Cetakan Ke Dua Puluh Enam. Manajemen Sumber Daya Manusia. Jakarta: PT. Bumi Aksara

Silalahi, U. (2013). Asas-asas Manajemen. PT Refika Aditama. Bandung

Sinambela, L.P. (2016). Manajemen Sumber Daya Manusia.Jakarta : PT Bumi Aksara

Sriekaningsih, A (2017). Pengaruh Kepemimpinan, Budaya Organisasi, dan Lingkungan Kerja Serta Kepuasan Kerja Terhadap Kinerja Pegawai Wilayah Kecamatan Kota Tarakan. Jurnal Borneo Administrator Vol 13(1)

Sugiyono, (2009).Metode Penelitian Bisnis. Cetakan ke Lima Belas, CV Alfa Beta

Sutrisno, E. (2018). Manajemen Sumber Daya Manusia. Prenada Media Group Jakarta

Wibowo. (2017). Cetakan Ke Dua Belas. Manajemen Kinerja. Depok : PT Raja Grafindo Persada Depok

\section{Copyrights}

Copyright for this article is retained by the author(s), with first publication rights granted to the journal.

This is an open-access article distributed under the terms and conditions of the Creative Commons Attribution license (http://creativecommons.org/licenses/by/4.0/) 